Ann. rheum. Dis. (1963), 22, 356.

\title{
CLINICAL ASSESSMENT OF A NEW PYRAZOLONE DERIVATIVE (KB 95)
}

\author{
BY \\ F. DUDLEY HART AND P. L. BOARDMAN \\ Westminster Hospital, London
}

KB 95 (Sandoz) is a new derivative of the pyrazolone series which has certain pharmacological similarities to phenylbutazone (Figure), though with a reported lower incidence of gastro-intestinal ulceration in the guinea-pig. Analgesic and anti-inflammatory properties have been demonstrated in mice. It is also said to have a weak antispasmodic effect on smooth muscle and to reduce emotional tension in the rat. In contradistinction to phenylbutazone, however, it has a pharmacologically demonstrable antiserotonin effect in the rat.

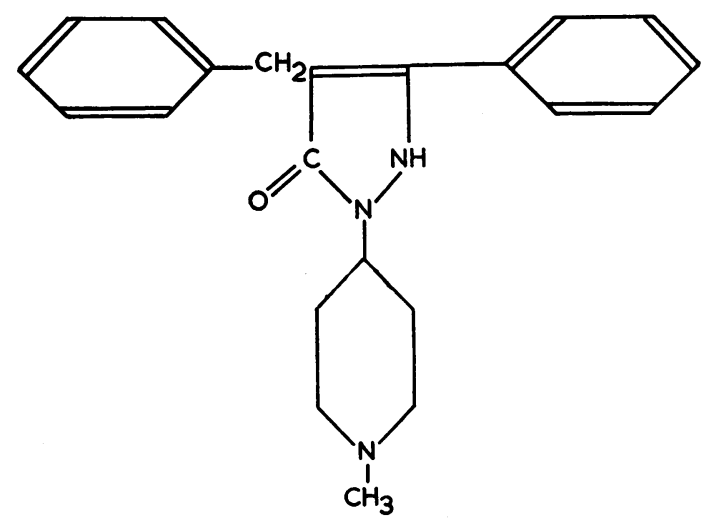

Figure.-Chemical formula of KB95.

As no clinical report is available, we present the results of a pilot trial in a small group of patients.

\section{Material}

A course of $\mathrm{KB} 95$ was given to thirty patients: eighteen with rheumatoid arthritis, nine with ankylosing spondylitis, and three with osteo-arthritis. Five of the patients with rheumatoid arthritis were admitted to hospital and received 7 to 14 days' therapy. The thirteen out-patients received therapy for 1 month. The patients were selected at $^{\circ}$ random, and all had had uncomplicated disease for at least one year with classical clinical and radiological features. Sheep-cell agglutination and latex-fixation tests were positive in twelve of the eighteen rheumatoid patients. Most had received analgesics for several months and had definite opinions as to their value.

\section{Method}

The out-patients received $300 \mathrm{mg}$. KB 95 three times a day for 1 month. They were asked to compare the effect with that obtained from other analgesics, in particular, salicylates, phenylbutazone, and paracetamol. Pain, stiffness, loosening-up time, comments on general health, capacity for physical activity, and side-effects were noted. Haemoglobin, white cell counts, urine, and protein flocculation and turbidity tests were carried out regularly. The in-patients, who all had rheumatoid arthritis, were assessed twice-weekly by standard jewellers' rings, strength of grip, and joint tenderness, and weekly by erythrocyte sedimentation rate. The patients also kept a daily diary of their own estimates of pain, stiffness, and loosening-up time. All measurements were carried out by one observer only (P.B.). No apparent clinical effect was accepted as due to the drug unless a deterioration occurred on its withdrawal.

\section{Results}

Rheumatoid Arthritis.-Ten of the eighteen patients had no change in their symptoms, one reported an increase in joint pain, and seven noted symptomatic improvement. Three patients compared the effect with phenylbutazone $(100 \mathrm{mg}$.) and considered the latter to be more efficient on a tabletfor-tablet basis, three found the relief similar to that obtained from aspirin ( $300 \mathrm{mg}$.), and four found the effect about the same as that of paracetamol (0.5$1 \mathrm{~g}$.$) .$

Only one patient improved dramatically. This was a lady with rheumatoid arthritis who did not tolerate phenylbutazone and remained comfortable on soluble aspirin ( $3 \cdot 7 \mathrm{~g}$.) daily, but showed marked symptomatic improvement on $\mathrm{KB} 95$. This one 
TABLE

SIDE-EFFECTS EXPERIENCED BY SIX OF THE THIRTY PATIENTS

\begin{tabular}{c|c|c|c|c|}
\hline Patient No. & Diagnosis & Drugs & Soluble Aspirin \\
\hline 1 & Rheumatoid arthritis & Phenylbutazone & Nil \\
\hline 2 & Rheumatoid arthritis & Dyspepsia & Nil & Abdominal pain \\
\hline 3 & Rheumatoid arthritis & Dyspepsia & Dyspepsia & Severe dyspepsia \\
\hline 4 & Rheumatoid arthritis & Nil & Dyspepsia \\
\hline 5 & Rheumatoid arthritis & Dyspepsia & Dyspepsia \\
\hline 6 & Ankylosing spondylitis & Nil & Nil \\
\hline
\end{tabular}

patient has continued to take the drug for 4 months without side-effects, but also without measurable evidence of anti-inflammatory activity. None of the five patients who were assessed and treated in hospital showed evidence of anti-inflammatory activity. Swelling at the proximal interphalangeal joints of the hands, as measured by jewellers' rings, did not change significantly and the erythrocyte sedimentation rates were unaffected.

Ankylosing Spondylitis.-Seven of the nine patients noted no therapeutic effect, and two reported slight symptomatic benefit, comparable to that obtained by small doses of soluble aspirin.

Osteo-Arthritis.-Two of the three patients had severe involvement of the knees and one had mild generalized disease. None noted any symptomatic improvement.

Side-Effects. - These occurred in six patients (Table): four with rheumatoid arthritis complained of dyspepsia (two of whom had similar symptoms on soluble aspirin) and one noted a sensation of abdominal distension. One patient with ankylosing spondylitis reported mental irritability.

\section{Discussion}

The symptomatic relief obtained from one capsule of KB 95 (300 mg.) was less than that from phenylbutazone (100 mg.) and approximately the same as that from aspirin (300 mg.) or paracetamol (0.5$1 \mathrm{~g}$.$) . Thus, a daily dose of 900 \mathrm{mg}$. KB 95 had no clear advantage over $900 \mathrm{mg}$. aspirin or 1.5-3 g. paracetamol.

\section{Summary}

A pilot scheme to assess the clinical activity of KB 95 demonstrated mild symptomatic relief in seven out of eighteen patients with rheumatoid arthritis, two out of nine with ankylosing spondylitis, and none of three with osteo-arthritis. No antiinflammatory action was demonstrated. Six of the thirty patients experienced mild side-effects.

We conclude that this substance offers no shortterm advantage over aspirin or paracetamol and, although a pyrazoline derivative, is in no way comparable to phenylbutazone as a therapeutic agent.

Our thanks are due to Dr. R. A. Ellis of the Research Department, Sandoz Products Ltd., for supplies of this drug.

\section{Evaluation clinique d'un nouveau dérivé de pyrazolone (KB 95)}

\section{RÉSUMÉ}

Un projet expérimental pour évaluer l'activité clinique de KB 95 démontra un soulagement symptomatique léger chez sept sur dix-huit malades atteints d'arthrite rhumatismale, deux sur neuf souffrant de spondylarthrite ankylosante et zéro sur trois malades ostéoarthritiques. On ne décéla pas d'action anti-inflammatoire. Six sur ces trente malades éprouvèrent de légers effets secondaires.

Nous concluons qu'à court terme cette substance n'offre aucun avantage sur l'aspirine ou le paracétamol et que, tout en étant un dérivé de pyrazolone, elle n'est en rien comparable à la phénylbutazone comme agent thérapeutique.

\section{Valoración clinica de un nuevo derivado de pirazolona (KB 95)}

\section{SUMARIO}

Un proyecto experimental para valorar la actividad clínica de KB 95 demostró un alivio sintomático ligero en siete de dieciocho enfermos con artritis reumatoide, en dos de nueve afectos de espondilartritis anquilosante y en ninguno de tres osteoartríticos. No se evidenció acción anti-inflamatoria alguna. Seis de los treinta enfermos acusaron efectos secundarios.

Concluimos que esta substancia no ofrece ventaja inmediata sobre la aspirina o el paracetamol y que, a pesar de ser un derivado de pirazolona, no se la puede comparar en su efecto terapéutico a la fenilbutazona. 